\title{
SEBUAH STUDI LITERATUR MENGENAI PENGUKURAN KINERJA RANTAI PASOK PADA INDUSTRI STRATEGIS DI INDONESIA
}

\author{
Joko Sulistio \\ Jurusan Teknik Industri, Fakultas Teknologi Industri, Universitas Islam Indonesia \\ Jl. Kaliurang Km 14,5 Sleman, Yogyakarta, 55501 \\ E-mail:jokosulistio@uii.ac.id
}

\begin{abstract}
Article 33 in 1945 constitution of the republic of indonesia is the essence of strategic industry operative. Consistent with supply chain management (scm), the objective is to fulfil costumer value. Therefore, scm performance measurement become significant. The current measurement was not developed from the article 33. This research objectives are to study the current measurement framework and to discover research gap to develop measurement framework suitable for strategic industry in indonesia. The method used in this research is systematic literature review. This study found that there is no performance measurement that developed upon article 33. Further performance measurement development is crucial to accommodate article 33 and grounded theory is promising for such work.
\end{abstract}

Keywords : Strategic Industry, Supply Chain Management, Performance Measurement, Article 33 Constitution of The Republic of Indonesia, Literature Study.

\section{PENDAHULUAN}

Pasal 33 ayat (2) Undang - Undang Dasar 1945 menyatakan bahwa cabang cabang produksi yang penting bagi negara dan yang menguasai hajat hidup orang banyak dikuasai oleh negara. Pada pasal selanjutnya dikatakan bahwa bumi dan air dan kekayaan yang terkandung didalamnya dikuasai oleh negara dan dipergunakan untuk sebesar-besar kemakmuran rakyat. Undang undang No. 3 tahun 2014 tentang perindustrian pasal 84 menyatakan bahwa cabang produksi yang menguasai hajat hidup orang banyak merupakan industri strategis. Lebih lanjut, pada ayat ketiga pasal yang sama, Penguasaan Industri Strategis oleh negara dilakukan melalui:
a. Pengaturan Kepemilikan.
b. Penetapan Kebijakan.
c. Pengaturan Perizinan.
d. Pengaturan Produksi, Distribusi, dan Harga.
e. Pengawasan.

Sehingga, jenis industri yang termasuk kedalam kategori strategis adalah perusahaan listrik, gas, jawatan kereta api, bank - bank besar dan beberapa industri dasar (ISEI, 2005). Dengan demikian, dalam konteks operasional, pemerintah bertanggung jawab atas eksplorasi, eksploitasi, produksi dan distribusi dari cabang produksi tersebut. Artinya pemerintah bertanggung jawab penuh atas perencanaan, pengelolaan dan pengendalian rantai pasok (Supply Chain Management) industri strategis di Indonesia.

Supply Chain Management (SCM) merupakan disiplin ilmu yang meliputi perencanaan dan manajemen dari seluruh aktivitas yang terlibat dalam pemilihan pemasok, pengadaan, dan seluruh aktivitas logistik lainnya. Termasuk didalamnya adalah koordinasi dan kolaborasi dengan jaringan rekanan seperti pemasok, agen, pihak ketiga dan konsumen (CSCMP, 2014). Supply Chain Management meliputi semua tahapan, baik langsung maupun tidak langsung, dalam memenuhi permintaan konsumen. Tidak hanya berkaitan dengan perusahaan manufaktur dan pemasok saja, namun juga perusahaan jasa pengangkutan, pergudangan, retailer, dan konsumen itu 
sendiri (S. Chopra, P. Meindl, 2001), (I. Pujawan, E. R. Mahendrawathi, 2010). Pada umumnya, perusahaan melakukan pengukuran kinerja SCM dengan metode yang telah mapan dan luas digunakan. Dengan demikian, perusahaan dapat melakukan benchmark dengan best practice dari perusahaan lain yang sejenis. Namun, perusahaan diindustri strategis memiliki aspek khas yang mungkin tidak dimiliki perusahaan lain diluar Indonesia. Kenyataan bahwa perusahaan di industri strategis merupakan manifestasi dari cita - cita luhur yang tertuang dalam pasal 33 UUD 1945, menuntut pengukuran kinerja yang juga khas dan dapat mengakomodasi hal tersebut.

Penelitian ini bertujuan untuk melakukan telaah terhadap metode - metode pengembangan framework pengukuran kinerja pada SCM. Selain itu, penelitian ini juga dilakukan untuk menemukan celah penelitian untuk mengembangkan framework yang sesuai untuk pengukuran kinerja SCM pada perusahaan diindustri strategis di Indonesia. Penelitian ini menggunakan kajian literatur untuk mencapai kedua tujuan tersebut.

\section{METODE PENELITIAN}

Kajian literatur didalam penelitian ini menggunakan pendekatan systematic literature review. mengadopsi (C. Badole dkk, 2012) dan (H. Keathley, E. Van Aken, 2013). Tahapan kajian literatur dimulai dengan :

1) Pemilihan artikel.

2) Review.

3) Klasifikasi menurut alat serta metode / metodologi.

4) Analisis temuan.

Artikel dikumpulkan dari berbagai sumber, namun mayoritas artikel didapatkan melalui Proquest, Google Scholar dan Portal Garuda. Agar memudahkan pembahasan, maka kajian literatur ini adan dibagi menjadi tiga bagian yaitu :
1) Penerjemahan Pasal 33 UUD 1945.

2) Penelitian tentang Supply Chain Management Performance Measurement.

3) Conceptual Framework.

\section{HASIL DAN PEMBAHASAN}

\subsection{Penerjemahan Pasal 33 UUD 1945}

Undang - Undang Dasar 1945 hadir dalam bentuk yang pasif dan abstrak. Abstrak karena bersifat sangat umum dan pasif karena tidak memiliki akibat secara hukum apabila tidak terjadi peristiwa yang konkrit (A. Firmansyah, 2012). Contohnya adalah ketika APHI (Asosiasi Penasehat Hukum dan Hak Asasi Manusia Indonesia), PBHI (Perhimpunan Bantuan Hukum dan Hak Asasi Manusia Indonesia), Yayasan 324, SNB (Solidaritas Nusa Bangsa) memandang bahwa Undang - Undang Nomor 22 Tahun 2001 tidak sesuai dengan Pasal 33 dalam UUD 1945. Selanjutnya, para pihak mengajukan permohonan untuk menguji konstitusionalitas dari keberlakuan kepada Mahkamah Konstitusi dengan Nomor Permohonan Perkara / PUU-I / 2003 (K. Magnar, dkk, 2010).

Pasal 33 UUD 1945 secara spesifik mengatur bagaimana perekonomian Indonesia seharusnya. Penelitian ditopik topik ekonomi masih jarang menyentuh level mikro, terlebih lagi masuk ke dalam ranah operasional. Konteks penguasaan negara atas cabang - cabang produksi yang menguasai hajat hidup orang banyak pada praktiknya harus berhadapan dengan perekonomian kapitalistik. Dari artikel jurnal yang dikumpulkan, ditemukan pembahasan pasal 33 UUD 1945 mayoritas menganalisis aspek hukum dari pasal tersebut. Upaya penafsiran pasal 33 UUD 1945 dilakukan dalam rangka mempelajari putusan Mahkamah Konstitusi terkait dengan Judicial Review UU No. 7/2004, UU No. 22/2001, dan UU No. 20/2002. Hal yang disoroti dalam artikel ini adalah mengenai kepemilikan badan usaha yang mengelola produk - produk yang menguasai hajat hidup orang banyak. 
Tabel 1. Klasifikasi Berdasarkan Metodologi dalam Publikasi LPG Bersubsidi

\begin{tabular}{|c|c|c|c|}
\hline No & Klasifikasi Model & Alat & Penulis \\
\hline 1 & Descriptive Analysis & Deskripsi & $\begin{array}{c}\text { S. Feriyanti, 2009, E. } \\
\text { Salangka, 2013, R. } \\
\text { Rosita, R. Basuki, } 2013\end{array}$ \\
\hline 2 & Inventory Model & EOQ \& ROP & $\begin{array}{l}\text { P. H. Saputra, Z. J. H. } \\
\text { Tarigan, } 2014\end{array}$ \\
\hline 3 & Linier Programming & $\begin{array}{c}\text { Goal Programming \& Linier } \\
\text { Programming }\end{array}$ & $\begin{array}{l}\text { F. Widad, I. N. Pujawan, } \\
\text { 2010, R. Wikramadewa, } \\
\text { dkk, 2011, D. Anggraini, } \\
\text { dkk, 2011, G. Anggoro, } \\
\text { F. Hadi, } 2011\end{array}$ \\
\hline 4 & Operation Research & $\begin{array}{l}\text { P-Median, Allocation Model \& } \\
\text { Minimum - Cost Method }\end{array}$ & $\begin{array}{c}\text { E. A. Kawi, A. } \\
\text { Rusdiansyah, 2009, } \\
\text { Muchlis, S. E. Wiratno, } \\
2013\end{array}$ \\
\hline 5 & Simulation Modeling & $\begin{array}{c}\text { Agent Based Modeling \& Discrete } \\
\text { Event System Simulation }\end{array}$ & $\begin{array}{l}\text { A. Cahyaningrum, T. M. } \\
\text { Simatupang, 2013, N. P. } \\
\text { A. Nariswari, I. N. } \\
\text { Pujawan, 2010 }\end{array}$ \\
\hline
\end{tabular}

Mahkamah Konstitusi memberikan batas, bahwa hal tersebut dimungkinkan selama peran negara menjadi dominan. Selanjutnya, faktor - faktor produksi sebagaimana dimaksud didalam Pasal 33 UUD 1945, tidak dapat diserahkan ke dalam mekanisme pasar semata namun dalam penentuan tarif harus terlihat peran negara didalamnya, melalui kebijakan penetapan harga (K. Magnar, dkk, 2010). Penelitian serupa juga dilakukan oleh (A. Firmansyah, 2012). Meskipun masih dalam ranah pembahasan aspek hukum, upaya penterjemahan pasal 33 UUD 1945 ketingkat operasional dilakukan dengan mengulas tentang aspek hukum dalam kontrak bagi hasil dalam industri pertambangan minyak dan gas (H. R. Susmiyati, 2006).

\subsection{Penelitian Tentang Supply Chain Management Measurement}

Supply Chain Management adalah jaringan perusahaan - perusahaan yang secara bersama - sama bekerja untuk menciptakan atau menghantarkan suatu produk ketangan pemakai akhir. Termasuk didalamnya adalah supplier, pabrik, distributor, toko atau ritel, serta perusahaan perusahaan pendukung seperti peruahaan jasa logistik (R. Cuthbertson, W. Piotrowicz, 2011). Sedangkan menurut Council of Supply Chain Management Profesional, SCM merupakan disiplin ilmu yang meliputi perencanaan dan manajemen dari seluruh aktivitas yang terlibat dalam pemilihan pemasok, pengadaan dan seluruh aktifitas logistik lainnya. Termasuk didalamnya adalah koordinasi dan kolaborasi dengan jaringan rekanan seperti pemasok, agen, pihak ketiga dan konsumen (P. Charan, dkk, 2008). Menurut definisi - definisi tersebut, tampak jelas kompleksitas yang dihadapi ketika perusahaan menerapkan Supply Chain Management.

Pencarian artikel scholarly journal di data base ProQuest dan ScienceDirect dengan kata kunci "supply chain" menghasilkan 372.641 artikel. Dalam lima tahun terakhir tema ini telah dipublikasikan sebanyak 116.125 artikel. Terminology Supply Chain Management telah berkembang ke dalam beberapa topik penelitian sebagaimana ditunjukkan oleh gambar 1. Topik - topik tersebut adalah :

1. Green Supply Chain Management.

2. Sustainable Supply Chain Management.

3. Closed-Loop Supply Chain Management.

4. Global Supply Chain Management. 


\section{Supply Chain Risk Management.}

Selanjutnya, topik tersebut terbagi menjadi tiga sub topik yaitu :

1. Desain, membahas mengenai rancangan supply chain yang meliputi fungsi fungsi seperti persediaan, pergudangan, transportasi, penjadwalan, pemeliharaan dan lain sebagainya.

2. Relation, berfokus pada analisis hubungan simpul - simpul dalam supply chain seperti hubungan dengan pemasok, distributor, agen, dan konsumen.

3. Performance Measurement, bagian ini mediskusikan tentang pengukuran kinerja dengan menggunakan metode dan alat yang sudah tersedia serta merancang framework untuk melakukan pengukuran kinerja.

Penelitian ini akan mendiskusikan performance measurement karena sebuah sistem akan sangat sulit untuk dapat ditingkatkan kinerjanya apabila tidak memiliki indikator yang dapat diukur, demikian juga dalam SCM.

Dalam menerapkan sebuah sistem, maka diperlukan suatu pengukuran untuk mengetahui efektifitas penerapan sistem tersebut. Terlebih dalam sebuah sistem dengan kompleksitas yang dimiliki oleh Supply chain management. Salah satu tujuan utama dari penerapan SCM adalah untuk mencapai efektifitas dan efisiensi sedemikian rupa sehingga dapat memuaskan pelanggannya (P. Charan, dkk, 2008). Oleh karena itu, penting sekali untuk dapat mengukur aspek - aspek operasional didalam supply chain.

Sudah banyak sekali alternatif metode pengukuran yang dapat digunakan untuk mengevaluasi kegiatan operasional perusahaan atau industri. Pengukuran tersebut umumnya memiliki karakteristik yang khas untuk perusahaan tertentu. Untuk itu, perusahaan perlu menggunakan pengukuran yang sesuai dengan karakteristik organisasinya (C. Elrod, dkk, 2013). Era liberalisasi, globalisasi, privatisasi, teknologi informasi dan perkembangan teknologi yang non-linier telah memaksa perusahaan untuk memikirkan ulang strateginya. Karena kinerja supply chain telah diterima sebagai hal yang berpengaruh dalam tindakan perusahaan, maka perusahaan perlu untuk mengembangkan metode pengukuran kinerja supply chain (P. Charan, dkk, 2008).

Pencarian artikel scholarly journal di data base ProQuest dan ScienceDirect dengan kata kunci "supply chain" menghasilkan 372.641 artikel. Dalam lima tahun terakhir tema ini telah dipublikasikan sebanyak 116.125 artikel. Terminology Supply Chain Management telah berkembang ke dalam beberapa topik penelitian sebagaimana ditunjukkan oleh gambar 1. Topik - topik tersebut adalah :

1. Green Supply Chain Management.

2. Sustainable Supply Chain Management.

3. Closed-Loop Supply Chain Management.

4. Global Supply Chain Management.

Selanjutnya, topik tersebut terbagi menjadi empat sub topik yaitu :

1. Desain, membahas mengenai rancangan supply chain yang meliputi fungsi-fungsi seperti persediaan, pergudangan, transportasi, penjadwalan, pemeliharaan dan lain sebagainya.

2. Relation, berfokus pada analisis hubungan simpul - simpul dalam supply chain seperti hubungan dengan pemasok, distributor, agen, dan konsumen.

3. Performance, bagian ini mediskusikan tentang pengukuran kinerja dengan menggunakan metode dan alat yang sudah tersedia serta merancang framework untuk melakukan pengukuran kinerja.

4. Risk Management, sub topik ini mendiskusikan analisis dari sisi resiko yang mengancam rantai pasok dan penanggulangannya. 
Cukup banyak penelitian dilakukan untuk mengembangkan metode pengukuran kinerja SCM. Penelitian-penelitian pada umumnya berupaya untuk memberikan model pengukuran yang cocok untuk organisasi tertentu. Secara umum pengukuran rantai pasok dapat dikategorikan menjadi dua aktifitas yaitu (1) Pengukuran rantai pasok dan metrik, serta (2) Peningkatan kinerja rantai pasok (P. Gopal, J. Thakkar, 2012). Dengan menggunakan pendekatan deduktif Gopal memiliki pemahaman bahwa organisasi perlu mengembangkan sistem pengukuran kinerja rantai pasok yang kuat namun tetap fleksibel untuk mengantisipasi perubahan yang terjadi.
Pada penelitian yang lain, pengukuran kinerja dapat dikelompokan menjadi empat yaitu financial costs, quality, time, dan flexibility (Elrod, dkk, 2013). Didalam penelitian itu, Elrod menawarkan rangkuman metrik, batasan-batasan serta rekomendasi dengan tujuan untuk mendorong manajer berhati - hati dalam mempertimbangkan dan memilih metrik pengukuran yang akan diterapkan pada rantai pasok tertentu. Lebih lanjut, tidak direkomendasikan untuk menggunakan seluruh pengukuran yang ditawarkannya melainkan memilih pengukuran yang paling penting bagi organisasi.



Gambar 1. Lingkup Penelitian SCM. 
Tabel 1. Klasifikasi Publikasi dengan Tema Supply Chain Performance Measurement

\begin{tabular}{|c|c|c|}
\hline Tujuan & Metode & Penulis \\
\hline $\begin{array}{l}\text { Mengkompilasi dan mensintesa element-elemen } \\
\text { yang penting terkait dengan pengukuran kinerja } \\
\text { SCM. }\end{array}$ & Studi literatur & Elrod , dkk, 2013 \\
\hline $\begin{array}{l}\text { Melaporkan review meyeluruh dari sistem } \\
\text { pengukuran kinerja SCM dan mengangkat isu-isu } \\
\text { penelitian baru }\end{array}$ & Studi literatur & $\begin{array}{l}\text { P. Gopal, J. } \\
\text { Thakkar, } 2012\end{array}$ \\
\hline $\begin{array}{l}\text { Mengusulkan framework pengukuran kinerja SCM } \\
\text { untuk perusahaan kecil dan menengah dengan } \\
\text { menggunakan pendekatan kualitatif dan kuantitatif }\end{array}$ & $\begin{array}{l}\text { Analisis studi } \\
\text { kasus, secondary } \\
\text { data, balanced } \\
\text { scorecard (BSC) } \\
\text { dan Supply Chain } \\
\text { Operation } \\
\text { Reference } \\
\text { (SCOR) } \\
\text { Interpretive }\end{array}$ & $\begin{array}{l}\text { J. Thakkar, dkk, } \\
2009\end{array}$ \\
\hline $\begin{array}{l}\text { Menentukan variabel kunci dalam implementasi } \\
\text { sistem pengukuran kinerja SCM }\end{array}$ & $\begin{array}{l}\text { Structural } \\
\text { Modeling (ISM)- } \\
\text { Based Approach }\end{array}$ & $\begin{array}{l}\text { P. Charan, dkk, } \\
2008\end{array}$ \\
\hline $\begin{array}{l}\text { mengulas dan mengevaluasi model } \\
\text { kinerja SCM dan menawuran } \\
\text { pengukuran kinerja SCM untuk } \\
\text { manufaktur }\end{array}$ & Studi literatur & $\begin{array}{l}\text { B. M. Beamon, } \\
1999\end{array}$ \\
\hline $\begin{array}{l}\text { Menawarkan framework pengukuran kinerja SCM } \\
\text { baru }\end{array}$ & $\begin{array}{l}\text { Balanced } \\
\text { Scorecard (BSC), } \\
\text { Analytic } \\
\text { Hierarchy Process } \\
\text { (AHP) and Data } \\
\text { Envelopment } \\
\text { Analysis (DEA) }\end{array}$ & $\begin{array}{l}\text { A. Tonanont, dkk, } \\
2008\end{array}$ \\
\hline $\begin{array}{l}\text { Mengevaluasi framework pengukuran kinerja } \\
\text { SCM dalam sektor agri-food }\end{array}$ & $\begin{array}{l}\text { Analisis studi } \\
\text { kasus, }\end{array}$ & $\begin{array}{l}\text { L. H. Aramyan, } \\
\text { dkk, } 2007\end{array}$ \\
\hline $\begin{array}{l}\text { Menawarkan framework untuk pengukuran kinerja } \\
\text { SCM dengan menganalisis temuan empiris }\end{array}$ & $\begin{array}{l}\text { Studi literatur dan } \\
\text { ilustrasi studi } \\
\text { kasus }\end{array}$ & $\begin{array}{l}\text { R. Cuthbertson, } \\
\text { W. Piotrowicz , } \\
2011\end{array}$ \\
\hline $\begin{array}{l}\text { Merancang ulang sistem pengukuran kinerja green } \\
\text { supply chain untuk produk pulp dan kertas }\end{array}$ & $\begin{array}{l}\text { Mathematical } \\
\text { Modeling }\end{array}$ & $\begin{array}{l}\text { H. Saputra, P. } \\
\text { Fithri, } 2012\end{array}$ \\
\hline $\begin{array}{l}\text { Mereview beberapa artikel penelitian yang penting } \\
\text { mengenai kinerja SCM }\end{array}$ & & $\begin{array}{l}\text { S. C. Singh, S. K. } \\
\text { Pandey, } 2013\end{array}$ \\
\hline
\end{tabular}

Sebuah analisis studi kasus dengan menggunakan Supply Chain Operational Reference (SCOR) yang dikombinasikan dengan Balance Score Card (BSC). Tujuannya adalah untuk mengusulkan sebuah framework pengukuran kinerja SCM untuk perusahaan kecil dan menengah dengan menggunakan pendekatan kualitatif dan kuantitatif. Penelitian tersebut menghasilkan sebuah framework pengukuran rantai pasok yang terintegrasi untuk mengevaluasi dan merencanakan aktifitas didalam organisasi Usaha Kecil dan Menengah (UKM). Framework yang dihasilkan meliputi pengukuran yang berwujud (tangible) dan yang tidak berwujud (intangible). Yang termasuk kedalam pengukuran berwujud adalah biaya, waktu, 
kapasitas, produktifitas dan utilitas. Sedangkan pengukuran yang tidak berwujud meliputi efektifitas, realibilitas, ketersediaan dan fleksibilitas (J. Thakkar, dkk, 2009).

Kesadaran organisasi akan pengukuran kinerja rantai pasok merupakan salah satu faktor pendorong kemajuan organisasi secara signifikan. Untuk itu, diperlukan upaya untuk mengidentifikasi variabel yang memberikan dampak pada implementasi sistem pengukuran kinerja rantai pasok. Model yang berbasis pada ISM telah dikembangkan untuk menganalisis interaksi antar variabel yang terlibat dalam pengukuran kinerja rantai pasok. lebih lanjut, dikembangkan hierarki tindakan - tindakan yang dapat diambil untuk implementasi sistem pengukuran kinerja rantai pasok sehingga pimpinan dimanajemen puncak dapat mengambil keputusan yang lebih baik saat mengimplementasikan sistem pengukuran kinerja rantai pasok. Dengan demikian organisasi akan memiliki rantai pasok yang efektif dan efisien (P. Charan, dkk, 2008).

Supply Chain Performance Measurement adalah sebuah proses yang context-dependent, dimana komponenkomponennya perlu disesuaikan terhadap kebutuhan organisasi secara spesifik. Untuk memahami bagaimana sistem pengukuran kinerja dikembangkan dan digunakan, maka organisasi perlu menangkap konteks, proses dan konten yang terkait dengan operasional rantai pasok (R. Cuthbertson, W. Piotrowicz, 2011).

Tiga tipe pengukuran kinerja yang diperlukan oleh setiap sistem pengukuran kinerja adalah: sumber daya (resource), output dan fleksibilitas (B. M. Beamon, 1999). Empat kategori utama dalam pengukuran kinerja (efisiensi, fleksibilitas, responsiveness dan kualitas produk) diidentifikasi sebagai komponen kunci pengukuran kinerja dalam produk pertanian (L. H. Aramyan, dkk, 2007).
Pengukuran kinerja disektor manufaktur memiliki beberapa aspek utama yang mendorong kinerja rantai pasok yaitu: berbagi informasi, perencanaan inventori, kolaborasi, pengurangan biaya, fleksibilitas, pengiriman, integrgasi dan utilisasi sumberdaya (S. C. Singh dan S. K. Pandey, 2013).

\subsection{Conceptual Framework}

Dari pemaparan sebelumnnya, tampak bahwa pengukuran kinerja dalam penerapan rantai pasok memiliki peran yang penting untuk mengembangkan rantai pasok yang efektif dan efisien. Di lain pihak, dalam bentuk penyajian yang lain pada tabel 3, terlihat bahwa pembahasan LPG bersubsidi belum menawarkan pengembangan dan penerapan sistem pengukuran kinerja rantai pasok. Sebaliknya, tidak ada sistem pengukuran rantai pasok yang telah diteliti pada sektor industri yang menguasai hajat hidup orang banyak sebagaimana diamanahkan UUD 1945 dipasal 33, yang dalam hal ini adalah rantai pasok LPG bersubsidi.

Sedangkan upaya menurunkan cita - cita pasal 33 UUD 1945 ke taraf operasional juga belum memadai, khususnya disektor industri. Untuk itu, terlebih dahulu diperlukan sebuah conceptual framework yang dapat digunakan sebagai landasan bagi upaya selanjutnya. Conceptual framework dapat didefinisikan sebagai jejaring konsep yang memberikan pemahaman menyeluruh akan suatu fenomena. Setiap konsep dari conceptual framework berperan untuk menjelaskan secara ontologi maupun epistemologi. Conceptual frameworks bukan merupakan kumpulan dari beberapa konsep melainkan sebuah bangunan dimana setiap konsep memiliki peran secara integral (Y. Jabareen, 2009).

Salah satu metode yang luas digunakan untuk membangun conceptual framework adalah grounded theory. Grounded Theory adalah teori umum dari metode ilmiah yang berurusan dengan generalisasi, elaborasi, dan validasi dari teori ilmu sosial. 
Tabel 3 Penggunaan Grounded Theory dalam penelitian SCM

\begin{tabular}{|c|c|c|}
\hline No & Tujuan & Penulis \\
\hline 1 & $\begin{array}{l}\text { Menyediakan framework untuk riset grounded theory dalam } \\
\text { logistik dan supply chain }\end{array}$ & $\begin{array}{l}\text { I. Manuj, } \\
\text { Pohlen, } 2012\end{array}$ \\
\hline 2 & $\begin{array}{l}\text { Menyelidiki dinamika dan dimensi dari perilaku pegawai } \\
\text { supply chain yang dapat menghalangi kesuksesan hubungan } \\
\text { dalam supply chain. }\end{array}$ & L. M. Thornton, 2013 \\
\hline 3 & $\begin{array}{l}\text { Menyediakan pedoman langkah demi langkah dalam rangka } \\
\text { meningkatkan pemahaman peneliti untuk menggunakan } \\
\text { metodologi grounded theory dalam konteks supply chain }\end{array}$ & $\begin{array}{l}\text { W. S. Randall, J. E } \\
\text { Mello, } 2012\end{array}$ \\
\hline 4 & $\begin{array}{l}\text { Memberikan contoh praktis dalam pengembangan teori } \\
\text { dengan menggunakan gounded theory pada implementasi } \\
\text { supply chain di Afrika Selatan }\end{array}$ & $\begin{array}{l}\text { I. M. Ambe, J. A } \\
\text { Badenhorst-Weiss, } \\
2011\end{array}$ \\
\hline 5 & $\begin{array}{l}\text { Meningkatkan kredibilitas penelitian SCM dengan grounded } \\
\text { theory }\end{array}$ & $\begin{array}{l}\text { L. Kaufmann, } \\
\text { Denk, } 2011\end{array}$ \\
\hline 6 & $\begin{array}{l}\text { Memeriksa kualitas penelitian dalam } \\
\text { menggunakan } \text { grounded theory }\end{array}$ & $\begin{array}{l}\text { N. Denk, } \\
\text { Kaufmann, C. } \\
\text { Carter, } 2012\end{array}$ \\
\hline 7 & $\begin{array}{l}\text { Menarik teori untuk memberikan pedoman bagi penelitian } \\
\text { yang mengangkat tema GSCM }\end{array}$ & $\begin{array}{l}\text { J. } \quad \text { Rauer, } \\
\text { Kaufmann, 2015 }\end{array}$ \\
\hline
\end{tabular}

Penelitian Grounded Theory perlu menemukan aturan yang dapat diterima untuk membentuk ilmu pengetahuan (konsistensi, kemampuan reproduksi, kemampuan generalisasi dan lain-lain). Tujuan umum dari penelitian Grounded Theory adalah (1) secara induktif memperoleh dari data, (2) yang diperlukan pengembangan teoritis, dan (3) yang diputuskan secara memadai untuk domainnya dengan memperhatikan sejumlah kriteria evaluatif (B. G. Glaser, A. L. Strauss, 1965). Pada awal perkembangannya, Grounded Theory banyak digunakan untuk ilmu-ilmu sosial. Meskipun demikian, saat ini disiplin ilmu lain juga memanfaatkan Grounded Theory sebagai salah satu metode yang kuat untuk membentuk conceptual framework. Demikian pula didalam topiktopik supply chain management.
Tabel 3 menyediakan informasi beberapa penelitian yang mencoba menganalisis penggunaan Ground Theory dalam Supply Chain Management. Secara umum, penelitian - penelitan tersebut berupaya untuk memberikan garis besar dan pedoman untuk melakukan penelitian dengan tema Supply Chain Management yang menggunakan Grounded Theory sebagai metodenya (I. Manuj, T. L. Pohlen, 2012), (W. S. Randall, J. E. Mello, 2012), (I. M. Ambe, J. A. Badenhorst-Weiss, 2011). Pedoman yang lebih spesifik dalam aplikasi Green Supply Chain Management diberikan oleh J. Rauer, L. Kaufmann, 2015. Sedangkan, upaya peningkatan kualitas penelitian secara konsisten dilakukan oleh (L. Kaufmann, N. Denk, 2011) dilanjutkan oleh (N. Denk, L. Kaufmann, C. R. Carter, 2012). 
Penggunaan Grounded Theory pada isu - isu SCM secara nyata ditunjukan pada penyelidikan dinamika dan dimensi dari perilaku pegawai supply chain yang dapat menghalangi kesuksesan hubungan dalam supply chain (L. M. Thornton, 2013).

\section{KESIMPULAN}

Dengan demikian, untuk dapat menyediakan pengukuran kinerja SCM yang mengakomodir pasal 33 UUD 1945 diperlukan sebuah conceptual framework yang berkualitas. Untuk itu, penggunaan Grounded Theory tampak menjanjikan hasil yang baik.

\section{DAFTAR PUSTAKA}

A. Cahyaningrum dan T. M. Simatupang, "An agent based model for the subsidized lpg with a closed distribution system," Business Process Management Journal, vol. 19, pp. 841-860, 2013.

A. Firmansyah, "Penafsiran Pasal 33 UUD 1945 dalam Membangun Perekonomian di Indonesia," Jurnal Ilmu Hukum Syiar Hukum, pp. 264288, 2012.

A. Tonanont, S. Yimsiri, W. Jitpitaklert dan K. Rogers, "Performance Evaluation in Reverse Logistics with Data Envelopment Analysis," Norcross, 2008.

Antara, "Antara News," 22 Agustus 2011. [Online]. Available: http://www.antaranews.com/berita/ 272891/pt-pertamina-segeraoperasi-pasar-lpg.

B. G. Glaser dan A. L. Strauss, "Discovery of Substantive Theory: A Basic Strategy Underlying Qualitative Research," The American Behavioral Scientist, pp. 5-13, 1965.
B. M. Beamon, "Measuring supply chain performance," International Journal of Operations \& Production Management, vol. 19, no. 3, pp. 275-292, 1999.

C. Badole, B. Nepal, R. Jain dan A. P. Rathore, "Supply Chain Modeling Scope and Methodology: A Review of Literature in the Last Decade," Norcross, 2012 .

C. Elrod, S. P. Murray dan S. Bande, "A Review of Performance Metrics for Supply Chain Management," Engineering Management Journal, vol. 25, no. 3, pp. 39-51, 2013.

CSCMP, “CSCMP," 2014. [Online]. Available: http://cscmp.org/aboutus/supply-chain-managementdefinitions.

CSCMP, "CSCMP," 2014. [Online]. Available: http://cscmp.org/aboutus/supply-chain-managementdefinitions.

D. Anggraini, I. N. Pujawan dan N. I. Arvitrida, "http://digilib.its.ac.id," 21 Juli 2011. [Online]. Available: http://digilib.its.ac.id/ITS-

Undergraduate3100011044832/17601/optimasijaringan-distribusi-lpg-3-kg-mulaidari-spbe-sampai-agen. [Diakses 2016].

E. A. Kawi dan A. Rusdiansyah, "Analisis penentuan lokasi pembangunan stasiun pengisian bulk elpiji (SPBE) untuk program konversi minyak tanah ke LPG $3 \mathrm{~kg}$ di propinsi Jawa Timur menggunakan metode Pmedian," Surabaya, 2009.

E. Salangka, "Penerapan akuntansi persediaan untuk perencanaan dan pengendalian LPG pada PT. Emigas Sejahtera Minahasa," Jurnal EMBA, vol. 1, no. 3, pp. 1120-1128, 2013. 
F. Widad dan I. N. Pujawan, "http://digilib.its.ac.id," 31 Mei 2010. [Online]. Available: http://digilib.its.ac.id/public/ITSUndergraduate-10667-Paper.pdf. [Diakses 2016].

F. Widad, "ITS," 2 Februari 2010. [Online]. Available:

http://digilib.its.ac.id/rancangankonfigurasi-jaringan-logistikdengan-pendekatan-sistem-tertutupstudi-kasus-distribusi-lpg-3-kg-dikabkota-malang-dan-kota-batu10667.html.

G. Anggoro dan F. Hadi, "http://digilib.its.ac.id," 16 Agustus 2011. [Online]. Available: http://digilib.its.ac.id/ITSUndergraduate-3100012045437/17643/perencanaan-sistemdistribusi-lpg-3-kilogram. [Diakses 2016].

H. Keathley dan E. Van Aken, "Systematic Literature Review on the Factors that Affect Performance Measurement System Implementation," Norcross, 2013.

H. R. Susmiyati, "Aspek Hukum Kontrak Bagi Hasil (Production Sharing Contract) dalam Pengusahaan Pertambangan Minyak dan Gas Bumi di Indonesia," Risalah Hukum, pp. 94-104, 2006.

I. M. Ambe dan J. A. Badenhorst-Weiss, "Grounded theory analysis of municipal supply chain management," African Journal of Business Management, pp. 1156211571, 2011.

I. Manuj dan T. L. Pohlen, "A reviewer's guide to the grounded theory methodology in logistics and supply chain management research," International Journal of Physical Distribution \& Logistics Management, pp. 784-803, 2012.
I. N. Pujawan dan E. R. Mahendrawathi, Supply Chain Management, Surabaya: Penerbit Guna Widya, 2010.

I. Pujawan dan E. R. Mahendrawathi, Supply Chain Management, Surabaya: Penerbit Guna Widya, 2010.

ISEI, Pemikiran dan permasalahan ekonomi di Indonesia dalam setengah abad terakhir: 1959-1966., Yogyakarta: KanisiuS, 2005.

J. Rauer dan L. Kaufmann, "Mitigating Eksternal Barriers to Implementing Green Supply Chain Management: a Grounded Theory Investigation of Green-Tech Companies Rare Earth Metals Supply Chain," Journal of Supply Chain Management, pp. 6588, 2015.

J. Thakkar, A. Kanda dan S. Deshmukh, "Supply chain performance measurement framework for small and medium scale enterprises," Benchmarking: An International Journal, vol. 16, no. 5, pp. 702-723, 2009.

K. Magnar, I. Junaenah dan G. A. Taufik, "Tafsir MK Atas Pasal 33 UUD 1945: Studi Atas Putusan MK Mengenai Judicial Review Terhadap UU No. 7/2004, UU No. 22/2001, dan UU No. 20/2002," Jurnal Konstitusi, pp. 111-180, 2010.

L. H. Aramyan, A. G.J.M., O. Lansink, J. G. van der Vorst dan O. van Kooten, "Performance measurement in agrifood supply chains: a case study," Supply Chain Management: An International Journal, vol. 12, no. 4, p. 304-315, 2007.

L. Kaufmann dan N. Denk, "How to Demonstrate Rigor When Presenting Grounded Theory Research in The Supply Chain Management Literature," Journal of Supply Chain Management, pp. 6472, 2011. 
L. M. Thornton, T. L. Esper dan M. L. Morris, "Exploring the impact of supply chain counterproductive work behaviors on supply chain relationships," International Journal of Physical Distribution \& Logistics Management, pp. 786804, 2013.

M. Oliez, "Sindonews," 30 Januari 2013. [Online]. Available: http://ekbis.sindonews.com/read/20 13/01/30/34/712694/lpg-3-kglangka-akibat-agen-dan-pengecernakal.

Muchlis dan S. E. Wiratno , "http://digilib.its.ac.id," 22 November 2013. [Online]. Available: http://digilib.its.ac.id/public/ITSpaper-27898-2508100162Paper.pdf. [Diakses 2016].

N. Denk, L. Kaufmann dan C. R. Carter, "Increasing the rigor of grounded theory research - a review of the SCM literature," International Journal of Physical Distribution \& Logistics Management, pp. 742763, 2012.

N. P. A. Nariswari dan I. N. Pujawan, "http://digilib.its.ac.id," 31 Mei 2010. [Online]. Available: http://digilib.its.ac.id/public/ITSUndergraduate-10669-Paper.pdf. [Diakses 2016].

P. Charan, R. Shankar dan R. K. Baisya, "Analysis of interactions among the variables of supply chain performance measurement system implementation," Business Process Management Journal, vol. 14, no. 4, pp. 512-529, 2008.
P. Gopal dan J. Thakkar, "A review on supply chain performance measures and metrics: 2000-2011," International Journal of Productivity and Performance Management, vol. 61, no. 5, pp. 518-547, 2012.

P. H. Saputra dan Z. J. H. Tarigan, "Analisa deskriptif manajemen persediaan pada PT. Usman Sinar Bulan, Sidoarjo," AGORA, vol. 2, no. 2, 2014.

R. Cuthbertson dan W. Piotrowicz, "Performance measurement systems in supply chains A framework for contextual analysis," International Journal of Productivity and Performance Management, vol. 60, no. 6, pp. 583-602, 2011.

R. Rosita dan R. Basuki, "Persepsi tingkat kepuasan keluarga di RT 03 RW 07 kelurahan Makasar - Jakarta Timur terhadap program konversi minyak tanah ke liquefied petroleum gas (LPG)," Jurnal Ilmiah WIDYA, vol. 1, no. 2, pp. 141-152, 2013.

R. Wikramadewa, I. N. Pujawan dan N. I. Arvitrida, "http://digilib.its.ac.id," 21 Juli 2011. [Online]. Available: http://digilib.its.ac.id/ITS-

Undergraduate3100011044832/17601/optimasijaringan-distribusi-lpg-3-kg-mulaidari-spbe-sampai-agen. [Diakses 2016].

Republika, "Republika Online," 15 Desember 2010. [Online]. Available: http://www.republika.co.id/berita/br eakingnews/ekonomi/10/12/15/1523242014-distribusi-lpg-3-kg-sistemtertutup-se-indonesia. 
S. C. Singh dan S. K. Pandey, "Supply Chain Performance: A Review of Literature," Journal of Supply Chain Management Systems, vol. 2, no. 1, pp. 1-12, 2013.

S. Chopra dan P. Meindl, Supply Chain Management: Strategy, Planning, and, New Jersey: Prentice Hall, 2001.

S. Feriyanti, "Evaluasi implementasi program konversi minyak tanah ke gas LPG $3 \mathrm{~kg}$ di kelurahan Aren Jaya kecamatan Bekasi Timur Kota Bekasi tahun 2007," Jurnal Ilmiah Administrasi Publik dan Pembangunan, vol. 3, no. 6, pp. 586-596, 2009.

T. Wahono, "Kompas," 12 Desember 2008. [Online].

Available: http://otomotif.kompas.com/read/20 08/12/12/17305912/wapres.janji.at asi.kelangkaan.elpiji.dalam.dua. hari.

Tempo, "Tempo," 15 Mei 2012. [Online]. Available:

http://www.tempo.co/read/news/20 12/05/15/058404049/PenyebabGas-Elpiji-3-Kilogram-Langka.

W. S. Randall dan J. E. Mello, "Grounded theory: an inductive method for supply chain research," International Journal of Physical Distribution \& Logistics Management, pp. 863-880, 2012.

Y. Jabareen, "Building a Conceptual Framework: Philosophy, Definitions, and Procedure," International Journal of Qualitative Methods, pp. 49-62, 2009. 